\title{
Are Imports and Exports \\ Cointegrated: the Case of Bulgaria \\ between 1967 and 2004
}

\section{Yannick Bineau}

\begin{abstract}
This note tests current account sustainability in Bulgaria from 1967 to 2004. Empirical analysis adopts various unit root and cointegration tests with structural breaks. Evidence of a long run relation between exports and imports in Bulgaria is shown, despite the financial crisis of 1996/8. Intertemporal current account constraint is not violated in Bulgaria.
\end{abstract}

Key words: Current account sustainability, Cointegration, Bulgaria.

JEL : C1, F14, F30.

\section{Introduction}

This study investigates the current account sustainability of Bulgaria, which remains important information for policymakers. Bulgaria has experienced persistent current account deficits, except between 1981-1984 under the Communist regime and during the 1996-1998 financial crisis. In 1997, Bulgaria adopted an exchange rate policy wherein the exchange rate is fixed against an external anchor regardless of the current account situation. In the short term, effects induced by current account deficits are not significant and unable to affect exchange rate parity. If Bulgaria is found not to be on a long-term, stable path, some policy variables may be changed, but exchange rate cannot. If Bulgaria is facing lasting current account imbalances, it could induce a forced adjustment process between sectors and might affect current account sustainability, and raise concern about exchange rate policy and nominal parity.

One way to evaluate current account sustainability is to analyse the long run relation between exports and imports with cointegration techniques. Using long run equilibrium relationships between imports and exports to test current account sustainability has been a technique that has received some attention in the past few years. Already, different forms of cointegration techniques have been implemented (Husted 1992; Wu, Fountas and Chen, 1996;
DOI: 10.2478/v10033-007-0005-1

Arize 2002; Narayan and Narayan, 2005). To the best of our knowledge, there have been no empirical studies on the sustainability of the current account applied to Bulgaria.

The rest of the paper is organized as follows. Section 2 briefly provides a theoretical background and describes the econometric issues. Section 3 provides data description and empirical results. Section 4 offers conclusions.

\section{Theoretical Background}

The theoretical basis is an intertemporal balance model. This framework is taken from Husted (1992). He models the behaviour of the stock of external debt to determine whether a country's intertemporal budget constraint is verified. The representative consumer's current-period budget constraint at period $t$ is given by:

$C_{t}=Y_{t}+B_{t}-I_{t}-\left(1+r_{t}\right) B_{t-1}$

*Yannick Bineau

EQUIPPE, Faculty of Economics, University of

Lille I, 59655 Villeneuve d'Asca Cedex, France

Tel. : +33 (0)3-20-33-63-58; Fax.: +33 (0)3-20-33-

70-97. Email : yannick.bineau@univ-lille1.fr 
Where $C_{t}, Y_{t}$ and $I_{t}$ are consumption, output and investment respectively; $r_{t}$ is a one-period world interest rate; $B_{t}$ describes international borrowing available to the consumer, which could be positive or negative. Initial debt size is $\left(1+r_{t}\right) B_{t-1}$. From the relation (1), the following expression for analysing the current account sustainability is derived:

$B_{t}-B_{t-1}=r_{t} B_{t-1}-N X_{t}$

Where $N X_{t}$ describes trade balance. In order to get a testable relation for the hypothesis of current account sustainability, Husted (1992) makes several assumptions. Equation 2 is transformed into the following expression:

$$
E X_{t}=\alpha_{0}+\alpha_{1} I M_{t}+\varepsilon_{t}
$$

Here $E X_{t}, I M_{t}$ are exports of goods and services, and imports of goods and services plus net transfer payments plus net interest payments, respectively. The letter $\varepsilon_{t}$ describes an error term.

Cointegration analysis is the methodology that is used if imports and exports are taken as a test of a country's intertemporal current account constraint. The procedure involves checking for integration order for each series. If a series has a unit root, cointegration regression stated by equation (3) is conducted. If the null of no-cointegration, the hypothesis that the two I(1) variables are not co-integrated, is rejected, this implies that one should accept the alternative hypothesis of co-integration between EXt and IMt . The series $\varepsilon_{t}$ is a stationary process and should not display a unit root. Then, three conclusions concerning the cointegrating vector $\left(1,-a_{1}\right)=(1,-1)$ and current account constraint may be established.

First, if co-integration cannot be proven, the current account deficits are unsustainable. There is no reason to conclude that $a_{1}=1$. Second, when there is proof of co- integration and if there a proof that $a_{1}=1$, then the current account deficit is sustainable. Third, if there is a cointegration relation between $E X_{t}$ and $I M_{t}$ and if $0<a_{1}<1$, intertemporal current account constraint might fail to be respected, because imports grow faster than exports and the hypothesis of sustainability of current accounts is violated. From previous studies that implemented this approach in the context of public finance (Hakkio and Rush 1991; Liu and Tanner 1995), it is possible to prove that if exports and imports are expressed as a percentage of GDP, it is necessary to have $a_{1}=1$ in order for the trajectory of the external debt to GDP not to diverge in an infinite horizon.

\section{Data and Estimation Results}

\section{Data}

Data was obtained from national accounts from the Bulgarian National Statistical Institute, from IMF's International Financial Statistics and from CEPII's data base. We used annual imports and exports from 1967 to 2004. This was the longest span available. All exports and imports data are divided by Bulgarian GDP and transformed into natural logarithms prior to econometric analysis.

\section{Unit Root Tests}

Table 1 shows the unit root results for imports and exports series. Bulgarian exports and imports followed random trajectories. The results show that both series are I(1), since the unit root null is rejected for level data, but not rejected for differenced data according to Augmented-Dickey-Fuller (ADF) and Phillips-Perron (PP) tests.

Such unit root tests assume that there are no structural

\begin{tabular}{|c|c|c|c|c|c|c|c|c|c|c|c|c|}
\hline & \multicolumn{6}{|c|}{ ADF } & \multicolumn{6}{|c|}{ PP } \\
\hline & 0.3025 & 0.0145 & 0.7545 & 74.16 & 0.5250 & 0.5250 & 0.3025 & 0.0145 & 0.7545 & 74.16 & 0.5250 & 0.5250 \\
\hline IM & -2.578 & 0.291 & -1.344 & 0.598 & -1.434 & 0.138 & -2.518 & 0.318 & -1.072 & 0.716 & -1.844 & 0.062 \\
\hline$E X$ & -2.672 & 0.253 & -1.631 & 0.456 & -1.466 & 0.131 & -2.561 & 0.298 & -1.439 & 0.552 & -2.210 & 0.027 \\
\hline IM-EX & -3.879 & 0.023 & -3.817 & 0.006 & -3.057 & 0.003 & -3.885 & 0.022 & -3.854 & 0.005 & -3.110 & 0.002 \\
\hline$\Delta I M$ & -5.487 & 0.000 & -5.562 & 0.000 & -5.513 & 0.000 & -8.387 & 0.000 & -8.076 & 0.000 & -5.567 & 0.000 \\
\hline$\Delta E X$ & -5.198 & 0.000 & -5.279 & 0.000 & -5.239 & 0.000 & -8.691 & 0.000 & -8.991 & 0.000 & -5.478 & 0.000 \\
\hline$\Delta(E X / I M)$ & -6.587 & 0.000 & -6.636 & 0.000 & -6.731 & 0.000 & -7.611 & 0.000 & -7.630 & 0.000 & -7.742 & 0.000 \\
\hline
\end{tabular}

Table 1.

Unit Root Tests on Exports and Imports (percent of GDP)

$T \zeta, T \mu$ and $T$ are the Dickey-Fuller and Phillips-Perron statistics with drift and trend, with drift, and without drift and trend, respectively.

The order of augmentation of the ADF tests (given in brackets) is selected by the Schwarz Bayesian criterion (SBC) using the

maximum order of 4. Critical values are taken from Mackinnon (1991). 


\begin{tabular}{|l|c|c|c|}
\hline & Break date $\boldsymbol{T}_{\boldsymbol{B}}$ & ADF test & Lags \\
\hline $\boldsymbol{I M}$ & 1979 & $-4.154^{\mathrm{a}}$ & 1 \\
\hline $\boldsymbol{E X}$ & 1993 & $-3.944^{\mathrm{a}}$ & 1 \\
\hline $\boldsymbol{I M}-\boldsymbol{E X}$ & 1992 & $-4.533^{\mathrm{a}}$ & 0 \\
\hline $\mathbf{\Delta I M}$ & 1989 & $-6.536^{\mathrm{a}}$ & 2 \\
\hline $\boldsymbol{D E X}$ & 1989 & $-6.925^{\mathrm{a}}$ & 2 \\
\hline $\boldsymbol{D ( E X / I M )}$ & 1992 & $-6.961^{\mathrm{a}}$ & 1 \\
\hline
\end{tabular}

\section{Table 2.}

Zivot and Andrews Test for Structural Change in

Exports and Imports (percent of GDP)

${ }^{a}{ }^{b}$ and ${ }^{c}$ denote statistical significance at the $1 \%, 5 \%$ and $10 \%$, level. respectively. Critical values from Zivot and Andrews (1992, table 4).

breaks in the series. Standard tests such as ADF or PP tests are ineffective. They are biased toward the non-rejection of the unit roots if a structural change in the trade function exists. This might be the case for Bulgaria. Following Zivot and Andrews' (1992) recursive approach, the null hypothesis that the series have unit root against the alternative of stationarity with endogoneous structural change was tested. An unknown break date was the value that minimised the -statistic. The break date was chosen endogeneously as a value over all possible break points. Table 2 provides the results of ADF test statistics proposed by Zivot and Andrews (1992) for the estimated break dates, the best-fitted regression of minimum -statistic and the minimum lag. The results show conclusive evidence in favor of unit roots for exports and imports series, and conclusive evidence of stationarity for current account deficits. The breaking date was unstable.

\section{Cointegration Tests}

The system-based method of Johansen and Julesius (1990) was used to test for the existence of cointegration relation between exports and imports. The results are shown in Table 3. Cointegration tests recommend the presence of one cointegrating vector between exports and imports. Unit root tests for the difference between exports to imports, which is the proxy for current account deficit, are also reported in Table 1. Following Gunlach and Sinn 1992, it was a direct cointegration test, where the cointegrating parameters were restricted to the values of zero (intercept) and one (slope). This empirical test showed that the current account deficit is sustainable for Bulgaria because the null hypothesis was rejected in favor of the alternative of stationarity.

\section{Long Run Relation Analysis}

Table 4 provides evidence for the long run relationship between series. The implementation of the dynamic ordinary least squares method (DOLS) suggested by Stock and Watson (1993) was performed. The DOLS procedure increases the cointegrating relationship with leads and lags in the first differences of the exogeneous regressors of equation observed to control feedback effects. Thus, it accounts for the endogeneity of the regressors and for serial correlation in the residuals. A simple OLS regression provides superconsistent estimates of the long run parameters. The t-statistic is based on the long run variance of the residuals instead of the contemporaneous variance, which is commonly used in OLS. The auto-regressive distributed lag approach

\begin{tabular}{|l|c|c|c|}
\hline \multicolumn{3}{|l|}{ Cointegration LR test based on maximal eigenvalue of the stochastic matrix } \\
\hline Null & Alternative & Statistics & 95\% Crit. Value \\
\hline $\mathrm{r}=0$ & $\mathrm{r}=1$ & 17.998 & 14.07 \\
\hline $\mathrm{r}<=1$ & $\mathrm{r}=2$ & 1.955 & 3.76 \\
\hline Cointegration LR test based on trace of the stochastic matrix \\
\hline Null & Alternative & Statistics & $95 \%$ Crit. Value \\
\hline $\mathrm{r}=0$ & $\mathrm{r}=1$ & 19.954 & 15.41 \\
\hline $\mathrm{r}<=1$ & $\mathrm{r}=2$ & 1.955 & 3.76 \\
\hline
\end{tabular}

Table 3.

Cointegration Tests

List of variables included in the cointegrated vector: EX, IM, intercept, and 37 observations for $1967-2004$, Maximum lag in VAR $=1$.

\begin{tabular}{|c|c|c|c|c|}
\hline & DOLS (1993) & DOLS (1993) & ARDL(2001) & ARDL(2001) \\
\hline $\begin{array}{l}\text { Lags (-) } \\
\text { leads (+) } \\
\text { structure }\end{array}$ & $(-3,+1)$ & $(-3,+1)$ & $(-2,+1)$ & $(-2,+2)$ \\
\hline$E C T$ & & & $-0.575(0.223)$ & $-0.560(0.236)$ \\
\hline$\alpha_{0}$ & $-0.054(0.052)$ & $-0.091(0.092)$ & $-0.049(0.051)$ & $-0.005(0.105)$ \\
\hline$\alpha_{1}$ & $0.975(0.048)$ & $0.944(0.079)$ & $0.955(0.074)$ & $1.017(0.154)$ \\
\hline$\alpha_{2} D_{t}$ & & $0.021(0.062)$ & & $-0.025(0.060)$ \\
\hline $\mathbf{R}^{2}$ & 0.962 & 0.962 & 0.862 & 0.820 \\
\hline Logl & 44.965 & 45.036 & 45.652 & 45.756 \\
\hline $\begin{array}{l}\mathrm{ADF}^{\mathrm{ac}} \text { on } \\
\text { residuals }\end{array}$ & $\begin{array}{c}-3.678 \\
(0)\end{array}$ & $\begin{array}{l}-3.721 \\
(0)\end{array}$ & $\begin{array}{l}-5.750 \\
(0)\end{array}$ & $\begin{array}{l}-5.798 \\
(0)\end{array}$ \\
\hline Cointegration $\mathbf{F}$ & & & 20.311 & 17.469 \\
\hline $\begin{array}{l}\text { Wald Test } \alpha_{I}=1 \\
\text { (p-value) }\end{array}$ & $\begin{array}{c}0.248 \\
(0.617)\end{array}$ & $\begin{array}{c}0.480 \\
(0.488)\end{array}$ & $\begin{array}{c}0.360 \\
(0.540)\end{array}$ & $\begin{array}{c}0.013 \\
(0.908)\end{array}$ \\
\hline
\end{tabular}

\section{Table 4.}

Long Run Relations between Exports and Imports (percent of GDP) ${ }^{b}$

$\mathrm{Dt}=0$ up to 1992 and 1 between 1993 and 2004.

${ }^{a}$ The critical value for the ADF statistics are $-3.626(1 \%),-2.945(5 \%)$

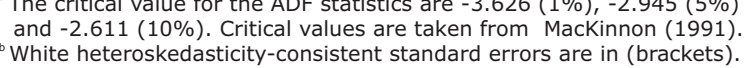

White heteroskedasticity-consistent standard errors are in
The order of augmentation of the ADF tests on residuals

[given in brackets] is selected by SBC using the maximum order of 4 . 
(ARDL) suggested by Pesaran, Smith and Shin (2001) was also adopted. The dependant variable in the first difference is regressed on the lagged values of the dependant and independant variables in levels and first differences.

In each case, optimal leads and lags were chosen from the Schwarz Bayesian criterion (SBC). Also, time break was taken into account as can be deduced from unit root tests. From Table 4, both methods confirm the existence of cointegration relation between exports and imports. Standard ADF tests applied to the residuals of each relation show that residuals are stationary. The inclusion of a dummy for trend break in 1992 did not induce significant change in the results. Estimates of range from -1.017 to -0.936 . Tests on the restriction of the null hypothesis that the coefficient = 1 were very conclusive. In all cases, Wald statistics were able to reject the alternative hypothesis that is different from unity. One can then conclude that the Bulgarian current account deficit was sustainable between 1967 and 2004.

\section{Conclusion}

This paper examined the Bulgaria's intertemporal budget constraint through the import-export correlation using annual data from 1967 to 2004. The latest cointegration techniques that consider the presence of possible regime changes on trade series showed that there was a long run relation between imports and exports over the period. From empirical findings, one can conclude that the Bulgarian current account deficit experienced over the past 30 years was sustainable.

Under these conditions, one can also conclude that the Bulgarian Currency Board Arrangement which implies the fixity, by the law, of the Bulgarian currency against the euro could last. Adoption of the euro could be eased. However, recent evolutions of the Bulgarian current accounts are likely to modify these results. The rise in domestic demand, induced by the strong growth of domestic credit strongly unbalanced the external current accounts through an increase in imports. The financing of these external imbalances via foreign direct investment inflows is likely to become exhausted in the longer term, because state owned companies are less numerous. International reserves might decrease and external debt might increase. Lastly, the trend of the European currency weakens the export sectors and increases the risks of imported inflation of this small economy. One way to respect long-term current account sustainability and to restore competitiveness would be to modify exchange rate parity.

\section{Acknowledgments}

This article was part of a common research project (Programme d'Actions Intégrées RILA Nº9806VG) between EQUIPPE (France), the Bulgarian Academy of Sciences and University Saint Kliment Ohridski, (Bulgaria). Special thanks to Iskra Balkanska-Christova (Bulgarian Academy of Sciences) for previous discussions.

\section{References}

Arize A., 2002, Imports and exports in 50 countries: tests of cointegration and structural breaks, International Review of Economics and Finance 11, 101-115.

Gunlach E. and S. Sinn, 1992, Unit roots tests for the current account balance: implications to international capital mobility, Applied Economics 24, 617-727.

Hakkio C. and M. Rush, 1991, Is the budget deficit 'too large'?, Economic Inquiry 4, 429-445.

Husted S., 1992, The emerging US current Account deficit in the 1980s: a cointegration analysis, The Review of Economics and Statistics 74, 159-166.

Johansen S. and K. Juselius, 1990, Maximum likelihood estimation and inference on cointegration with applications for the demand for money, Bulletin of Economics and Statistics, 52, 169-210.

Liu P. and E. Tanner, 1995, Intertemporal solvency and breaks in the US deficit process: a maximum likelihood cointegration approach, Applied Economics Letters 2, 231-235.

MacKinnon J., 1991, Critical values for cointegration tests, in R.F. Engle and C.W.J. Granger, eds., Long Run Relation-ships: Readings in Cointegration, (Oxford University Press) 267-76.

Narayan P. K. and S. Narayan, 2005, Are exports and imports cointegrated? Evidence from 22 least developed countries, Applied Economics Letters, 12, 375-378.

Pesaran M. H., Y. Shin and R. J. Smith, 2001, Bounds testing approaches to the analysis of level relationships, Journal of Applied Econometrics 16, 289-326.

Stock J. H. and M. Watson, 1993, A simple estimator of cointegrating vectors in higher order integrated systems, Econometrica 61, 783-820.

Wu J.-1, S. Fountas \& S.-1 Chen, 1996, Testing for the sustainability of the current account deficit in two industrial countries, Economics Letters, 52, 193-198.

Zivot E. and D. Andrews, 1992, Further evidence on the Great Crash, the oil-price shock, and the unit-root hypthesis, Journal of Business and Economic Statistics 10, 251-270. 